\title{
Effect of suppression of plasma prolactin on ovulation, plasma gonadotrophins and corpus luteum function in LH-RH-treated anoestrous ewes
}

\author{
A. S. McNeilly and R. B. Land* \\ M.R.C. Unit of Reproductive Biology, 2 Forrest Road, Edinburgh EHI $2 Q W$, and *A.R.C. \\ Animal Breeding Research Organisation, West Mains Road, Edinburgh EH9 3JQ, U.K.
}

\begin{abstract}
Summary. Nineteen Scottish Blackface ewes were given LH-RH $(3 \times 30 \mu \mathrm{g}$ i.v., 90 min intervals) during anoestrus when prolactin levels were elevated. Plasma levels of prolactin were suppressed with CB 154 (twice daily, i.m.) on Days -5 to $0(\mathrm{~N}=5)$, 0 to $+5(\mathrm{~N}=5)$ or -5 to $+5(\mathrm{~N}=5)$ around the day of LH-RH treatment (Day $0)$. Control animals $(\mathrm{N}=4)$ received saline on Days -5 to +5 . Nine animals ovulated forming corpora lutea as judged by laparoscopy on Day +7 . No difference in FSH or LH levels was found between treatments and ovulations occurred equally in all treatment groups. Progesterone levels were $<1 \mathrm{ng} / \mathrm{ml}$ in all animals up to Day 14. It is concluded that short-term suppression of prolactin does not affect the incidence of ovulation or corpus luteum progesterone production in LH-RH-treated anoestrous ewes.
\end{abstract}

\section{Introduction}

Seasonal anoestrus in the ewe is associated with an absence of ovulation and corpus luteum (CL) function and decreased sensitivity to the positive feedback and increased sensitivity to the negative feedback effects of oestrogen on luteinizing hormone $(\mathrm{LH})$ secretion (Land, Wheeler \& Carr, 1976; Legan, Karsch \& Foster, 1977). Serum levels of follicle-stimulating hormone (FSH) are not significantly different from levels seen during the oestrous cycle but serum levels of prolactin increase just before and remain elevated throughout seasonal anoestrus and fall before the onset of oestrous cyclicity in the autumn (Walton, McNeilly, McNeilly \& Cunningham, 1977).

While ovulation has been induced by single or multiple injections or infusions of $\mathrm{LH}-\mathrm{RH}$ in seasonally anoestrous ewes, the resulting CL fails to secrete normal amounts of progesterone (Crighton, Foster, Haresign, Haynes \& Lamming, 1973; Crighton, Foster, Haresign \& Scott, 1975; Haresign, Foster, Crighton, Haynes \& Lamming, 1975; Shareha, Ward \& Birchall, 1976). It was originally suggested that this was due to an inadequate release of $\mathbf{L H}$ at the time of ovulation (Crighton et al., 1975). However, PMSG pretreatment of these ewes results in a fully functional $\mathrm{CL}$, suggesting that failure of normal luteal function is probably due to inadequate gonadotrophin priming before the ovulatory surge of LH rather than to inadequacy of the surge of LH itself (Haresign \& Lamming, 1978).

Nevertheless, the possibility that the elevated levels of prolactin associated with anoestrus may directly affect the function of the $C L$ in sheep has not been examined. Lactational, pathological or pharmacologically induced hyperprolactinaemia in women is associated with absent or reduced luteal function (for references see Robyn et al., 1977; McNeilly, 1979). High levels of prolactin reduce progesterone output from human granulosa cells in vitro (McNatty, Sawers \& McNeilly, 1974) and suppress progesterone secretion and delay reactivation of the 
quiescent CL of the tammar wallaby (Tyndale-Biscoe \& Hawkins, 1977). Rhind, Chesworth \& Robinson (1978) found a reduced output of progesterone by the CL of pregnant ewes at times when serum levels of prolactin were seasonally elevated.

In order to determine whether elevated serum levels of prolactin suppress progesterone output from CL formed during anoestrus we have assessed the effect of suppression of serum levels of prolactin on ovulation and luteal function in anoestrous ewes treated with LH-RH.

\section{Materials and Methods}

\section{Animals and treatments}

Experiments were carried out in early August during anoestrus. Nineteen Scottish Blackface ewes were housed indoors under natural illumination and randomly allocated to one of four groups. All ewes were given three i.v. injections of $30 \mu \mathrm{g}$ synthetic LH-RH (Hoechst) at 90-min intervals $(10: 00,11: 30$ and 13:00 h) on Day 0 . The 4 treatments consisted of daily injections at 09:00 and 21:00 h of saline $(0.9 \%(\mathrm{w} / \mathrm{v}) \mathrm{NaCl})$ from Day -5 to Day +5 , or CB $154(100 \mu \mathrm{g}$ $2 \alpha$-bromo-ergocryptine i.m.: Sandoz) from Days -5 to 0,0 to +5 or -5 to +5 . First and last injections were given at 09:00 and 21:00 h respectively.

\section{Ovarian activity}

The ovaries of all ewes were examined by laparoscopy performed under barbiturate anaesthesia 6 days before LH-RH treatment; it was established that all ewes were acyclic since no CL were present. Laparoscopy was repeated 7 days after LH-RH treatment to see if any new CL had been formed.

\section{Blood sampling and hormone estimations}

Daily jugular venous blood samples were taken from all animals at 09:00 h on each of Days -6 to +14 , and immediately before any treatment injection on that day. On Day 0 , samples were collected at 30 -min intervals from $1 \mathrm{~h}$ before to $3 \mathrm{~h}$ after the first injection, and subsequently every 1 or $2 \mathrm{~h}$ until $23 \mathrm{~h}$ after the first LH-RH injection. Blood samples were collected into heparinized evacuated tubes, separated by centrifugation and stored at $-20^{\circ} \mathrm{C}$ until assayed.

Prolactin, LH, FSH and progesterone were measured in duplicate by radioimmunoassays previously described in detail (McNeilly \& Andrews, 1974; Baird, Burger, Heavon-Jones \& Scaramuzzi, 1974; McNeilly, McNeilly, Walton \& Cunningham, 1976; Martensz, Baird, Scaramuzzi \& Van Look, 1976). The sensitivities of the assays were $0.05 \mathrm{ng}$ prolactin (NIH PS6)/ml, 0.1 ng LH (NIH-LH-S14)/ml and $16 \mathrm{ng} \mathrm{FSH} \mathrm{(NIH-FSH-S10)/ml.} \mathrm{All} \mathrm{samples} \mathrm{were}$ analysed in one assay for each hormone. The intra-assay variations, as coefficient of variation (\%) of three quality control sera (at 30,55 and $80 \% \mathrm{~B} / \mathrm{Bo}$ ), were 7,6 and $9 \%$ for prolactin, $\mathrm{LH}$ and FSH respectively.

\section{Statistical analysis}

Results were analysed by Student's $t$ test or analysis of variance.

\section{Effect of CB 154 on daily blood levels of hormone \\ Results}

In control animals daily prolactin levels varied between 5 and $140 \mathrm{ng} / \mathrm{ml}$ (Text-fig. 1). During periods of treatment with CB 154 plasma levels of prolactin remained suppressed in all groups (range 0.5 to $2 \mathrm{ng} / \mathrm{ml}$; Text-fig. 1). CB 154 caused an abrupt decline in plasma levels of prolactin within $30 \mathrm{~min}$ of injection and these low values of $0.5-1.5 \mathrm{ng} / \mathrm{ml}$ were maintained for at least $12 \mathrm{~h}$. 


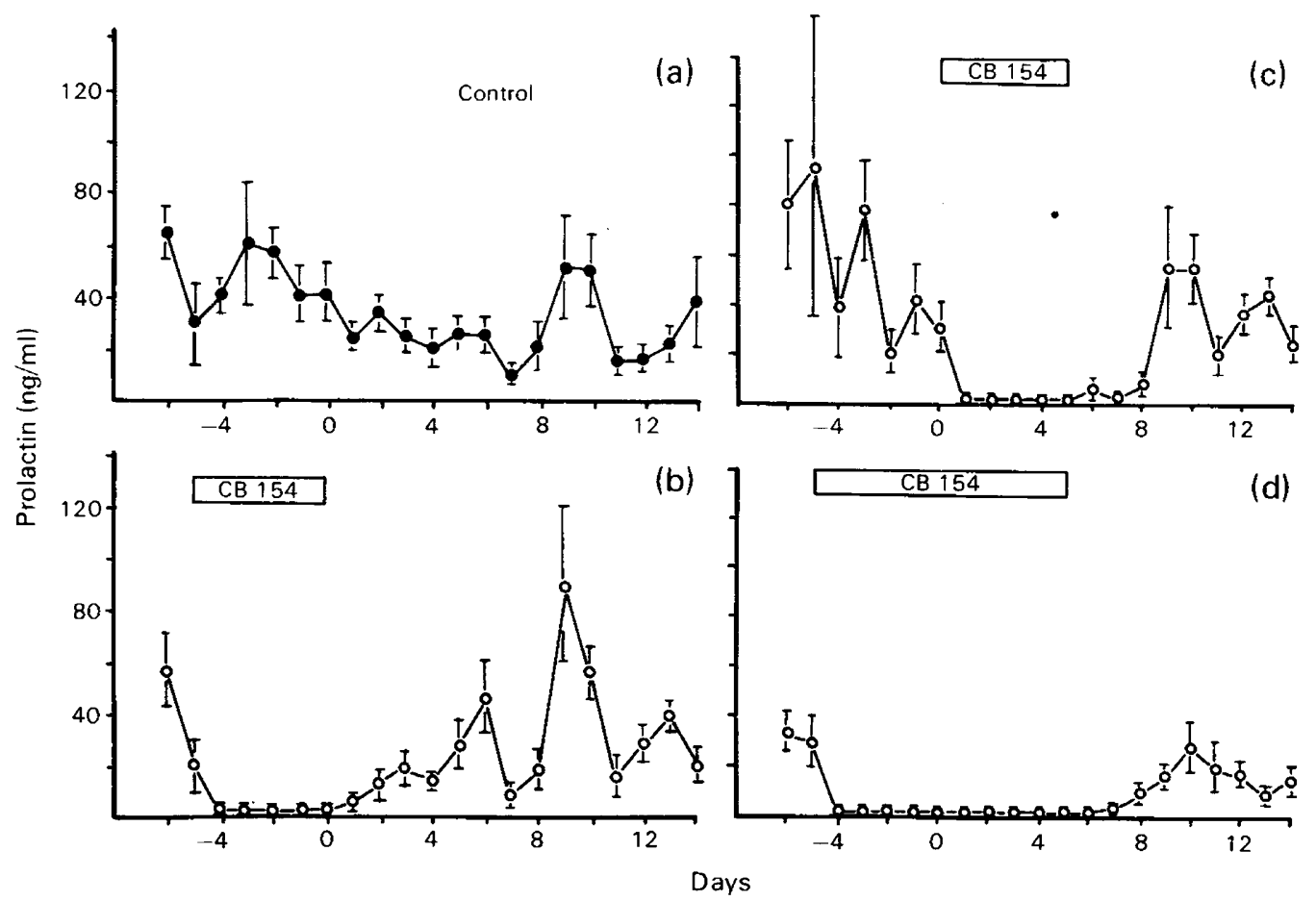

Text-fig. 1. Effect of CB 154, $100 \mu \mathrm{g}$ i.m. twice daily at 09:00 and 21:00 h (horizontal bars), on mean \pm s.e.m. daily plasma concentrations of prolactin in ewes before and after LH-RH injection (Day 0). (a) $\mathrm{N}=4$; (b) (c) and (d) $\mathrm{N}=5$.

During the 5-day period before LH-RH (Days - 5 to -1 ), CB 154 had no effect on mean ( \pm s.e.m.) daily plasma levels of LH $(0.69 \pm 0.10 \mathrm{ng} / \mathrm{ml}$ in untreated ewes (saline) and those treated with $\mathrm{CB} 154$ from Days 0 to $+5, n=45$, compared with $0.63 \pm 0.05 \mathrm{ng} / \mathrm{ml}$ in the ewes treated with CB 154 from Days -5 to 0 and -5 to $+5 ; n=50$ ). Daily plasma levels of FSH were also unaffacted by CB $154(103 \pm 11 \mathrm{ng} / \mathrm{ml}$ in untreated ewes and $80 \pm 8 \mathrm{ng} / \mathrm{ml}$ in CB 154 treated ewes).

\section{$L H$ and $F S H$ response to $L H-R H$}

$L H$. The injection of LH-RH caused an increase in the plasma concentration of $\mathrm{LH}$ in all animals. The pattern of response was similar in all groups (Text-fig. 2) with an initial increment of between 2 and $28 \mathrm{ng} / \mathrm{ml}$ (mean $10 \mathrm{ng} / \mathrm{ml}$ ) by $30 \mathrm{~min}$ after the first injection of LH-RH. A much greater increase (mean increment $33 \mathrm{ng} / \mathrm{ml}$ : range $13-67 \mathrm{ng} / \mathrm{ml}$ ) occurred by $30 \mathrm{~min}$ after the second injection of $\mathrm{LH}-\mathrm{RH}$ relative to the concentration at the time of injection, while the third injection appeared ineffective, the concentration of LH increasing in only 9 of the 19 animals. The overall pattern of response was the same in those animals which ovulated and those which failed to ovulate (Text-fig. 3). A comparison of the cumulative LH release over the $8 \mathrm{~h}$ after the first LH-RH injection showed no significant differences between treatment groups or between those animals which did or did not ovulate (Table 1). The amount of LH released in the ewes treated with CB 154 from Days 0 to +5 was reduced compared to the control but this did not achieve significance $(P=0 \cdot 1)$. The duration of response, as defined by the time taken for levels to return to preinjection values, was $7 \mathrm{~h}$ in 18 out of 19 animals and $9 \mathrm{~h}$ in the remaining animal. 


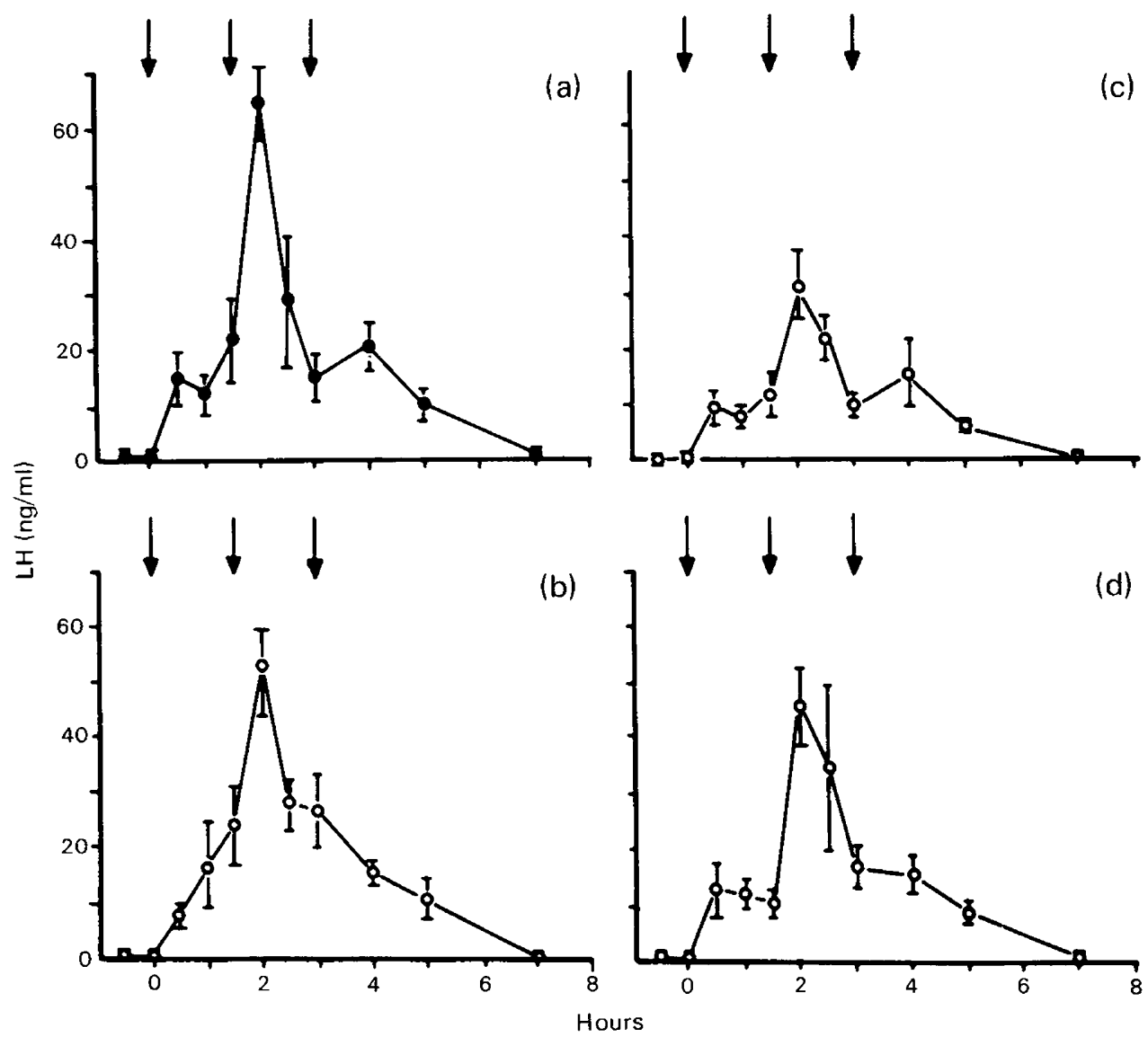

Text-fig. 2. Changes in the mean \pm s.e.m. plasma concentration of $L H$ in ewes after 3 i.v. injections of $30 \mu \mathrm{g} \mathrm{LH}-\mathrm{RH}$ at 90 -min intervals (arrows). (a) Saline-treated controls, $\mathrm{N}=4$; (b) CB 154 injected from -5 to 0 days, $\mathrm{N}=5$; (c) $\mathrm{CB} 154$ injected from 0 to +5 days, $\mathrm{N}=5$; (d) $\mathrm{CB} 154$ injected from -5 to +5 days, $\mathrm{N}=5$, relative to day of LH-RH treatment (Day 0).

Table 1. The release of LH and FSH (as cumulative totals) after 3 injections of $\mathrm{LH}-\mathrm{RH}$ in anoestrous ewes treated with CB 154

\begin{tabular}{|c|c|c|c|c|c|c|}
\hline \multirow[b]{2}{*}{ Treatment } & \multirow{2}{*}{$\begin{array}{l}\text { No. } \\
\text { of ewes }\end{array}$} & \multicolumn{3}{|c|}{ Cumulative FSH release $(\mathrm{ng} / \mathrm{ml})$} & \multirow{2}{*}{$\begin{array}{c}\text { Ratio of FSH } \\
\text { release } \\
0-7: 8-19\end{array}$} & \multirow{2}{*}{$\begin{array}{c}\text { Cumulative } \\
\text { LH release } \\
(\mathrm{ng} / \mathrm{ml}) \\
(0-8 \mathrm{~h})\end{array}$} \\
\hline & & $0-7 \mathrm{~h}$ & $8-19 \mathrm{~h}$ & $0-19 \mathrm{~h}$ & & \\
\hline None (controls) & 4 & $620 \pm 82$ & $1027 \pm 49$ & $1639 \pm 83$ & $1.79 \pm 0.29$ & $190 \pm 33$ \\
\hline CB 154 , Days -5 to 0 & 5 & $630 \pm 88$ & $869 \pm 100$ & $1500 \pm 124$ & $1.53 \pm 0.25$ & $187 \pm 31$ \\
\hline CB 154, Days 0 to +5 & 5 & $509 \pm 56$ & $678 \pm 174$ & $1187 \pm 185$ & $1.43 \pm 0.37$ & $119 \pm 18$ \\
\hline CB 154, Days -5 to +5 & 5 & $524 \pm 72$ & $691 \pm 82$ & $1215 \pm 110$ & $1.46 \pm 0.32$ & $159 \pm 22$ \\
\hline Ovulating* & 9 & $480 \pm 38$ & $896 \pm 94$ & $1373 \pm 115$ & $1.94 \pm 0.22$ & $166 \pm 24$ \\
\hline Not ovulating* & 10 & $648 \pm 50$ & $723 \pm 78$ & $1371 \pm 107$ & $1.23 \pm 0.15$ & $159 \pm 16$ \\
\hline
\end{tabular}

Values are mean \pm s.e.m. Times are relative to first injection of LH-RH $(0 \mathrm{~h})$.

* Results from all 4 treatments combined. 

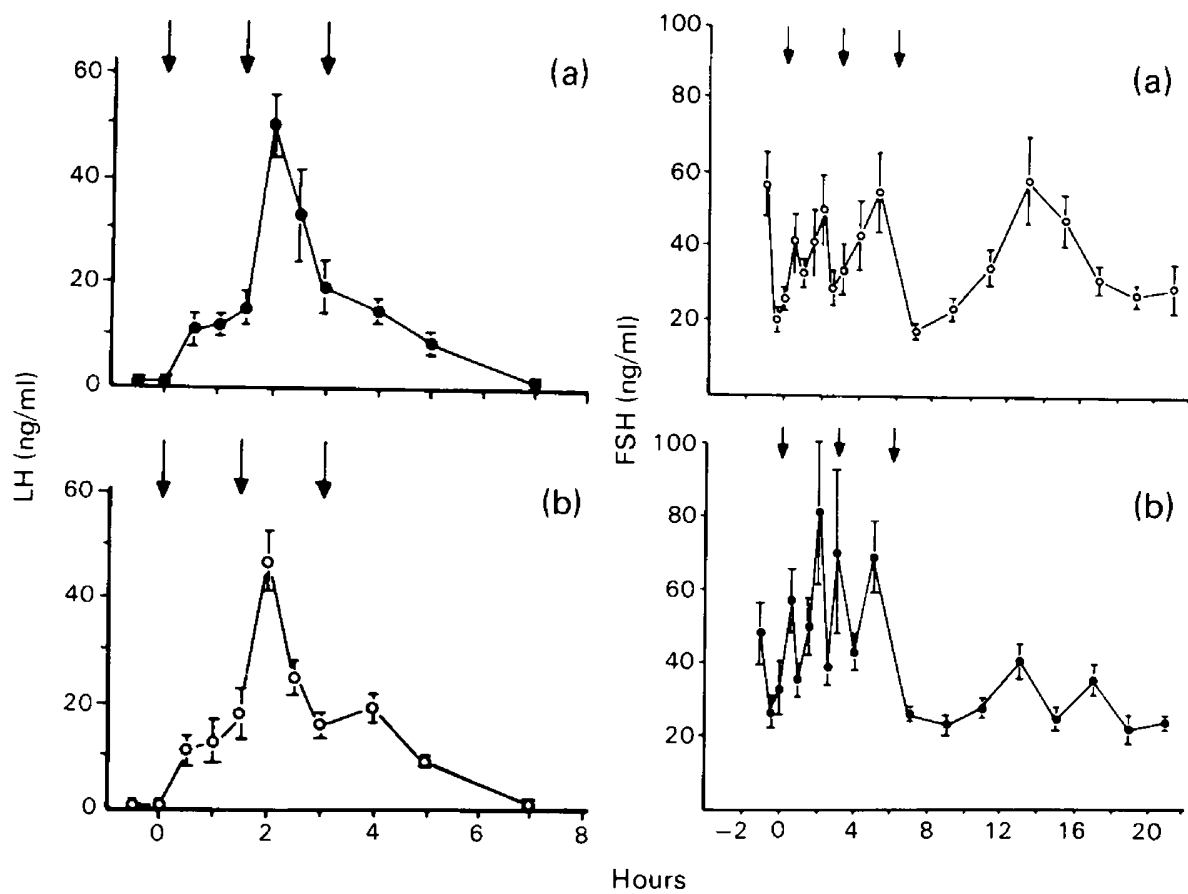

Text-fig. 3. Changes in the mean \pm s.e.m. plasma concentration of LH and FSH after 3 i.v. injections of $30 \mu \mathrm{g}$ LH-RH at 90-min intervals (arrows) in animals which subsequently did (a; $\mathrm{N}=9)$ or did not $(\mathrm{b} ; \mathrm{N}=10)$ ovulate.

FSH. LH-RH caused an increase in the plasma concentration of FSH within $30 \mathrm{~min}$ in 17 out of 19 animals after both the first and the second injections, 1 ewe responded to the first and not the second injection while the other responded to the second and not the first injection. No immediate response was seen after the third injection of LH-RH although a rise in the plasma concentration of FSH occurred in 10 out of 19 animals $11-13 \mathrm{~h}$ after the first injection (5-7 h after the last injection of LH-RH; Text-fig. 4). Estimation of the amount of FSH released (as the cumulative total of serum FSH values) between 0 and $7 \mathrm{~h}$ after the initial injection of LH-RH showed no statistically significant differences between the four groups (Table 1, Text-fig. 4). However, animals treated with CB 154 between -5 and +5 days after LH-RH released less FSH between 8 and $19 \mathrm{~h}$ after the initial injection of LH-RH than did controls $(691 \pm 82$ versus $1027 \pm 49 \mathrm{ng} / \mathrm{ml} ; P<0.02$; Table 1$)$. In addition, the overall amount of FSH released in response to LH-RH $(0$ to $19 \mathrm{~h})$ was significantly less $(P<0.02)$ in animals treated with CB 154 (CB 154 on Days -5 to +5 and -5 to 0 ) than in animals not injected with CB 154 at the time of LH-RH injection (Day 0).

The total FSH response between 0 and $19 \mathrm{~h}$ after the initial injection of LH-RH was the same in animals which ovulated as in those which did not (Table 1). However, significantly less $(P<0.02)$ FSH was released in the initial response period $(0-7 \mathrm{~h})$ by the animals that ovulated and more FSH was released in the second response period $(8-19 \mathrm{~h})$ than in those which did not ovulate (Text-fig. 3b; Table 1). The ratio of the amount of FSH released between 8 and $18 \mathrm{~h}$ and 0 and $7 \mathrm{~h}$ was greater than 1.4 in 8 out of the 9 animals which ovulated. In contrast this ratio was greater than 1.4 in only 1 out of the 10 animals which failed to ovulate. There was no difference in the basal levels of FSH in the 6 days before LH-RH treatment in animals which did or did not ovulate. 


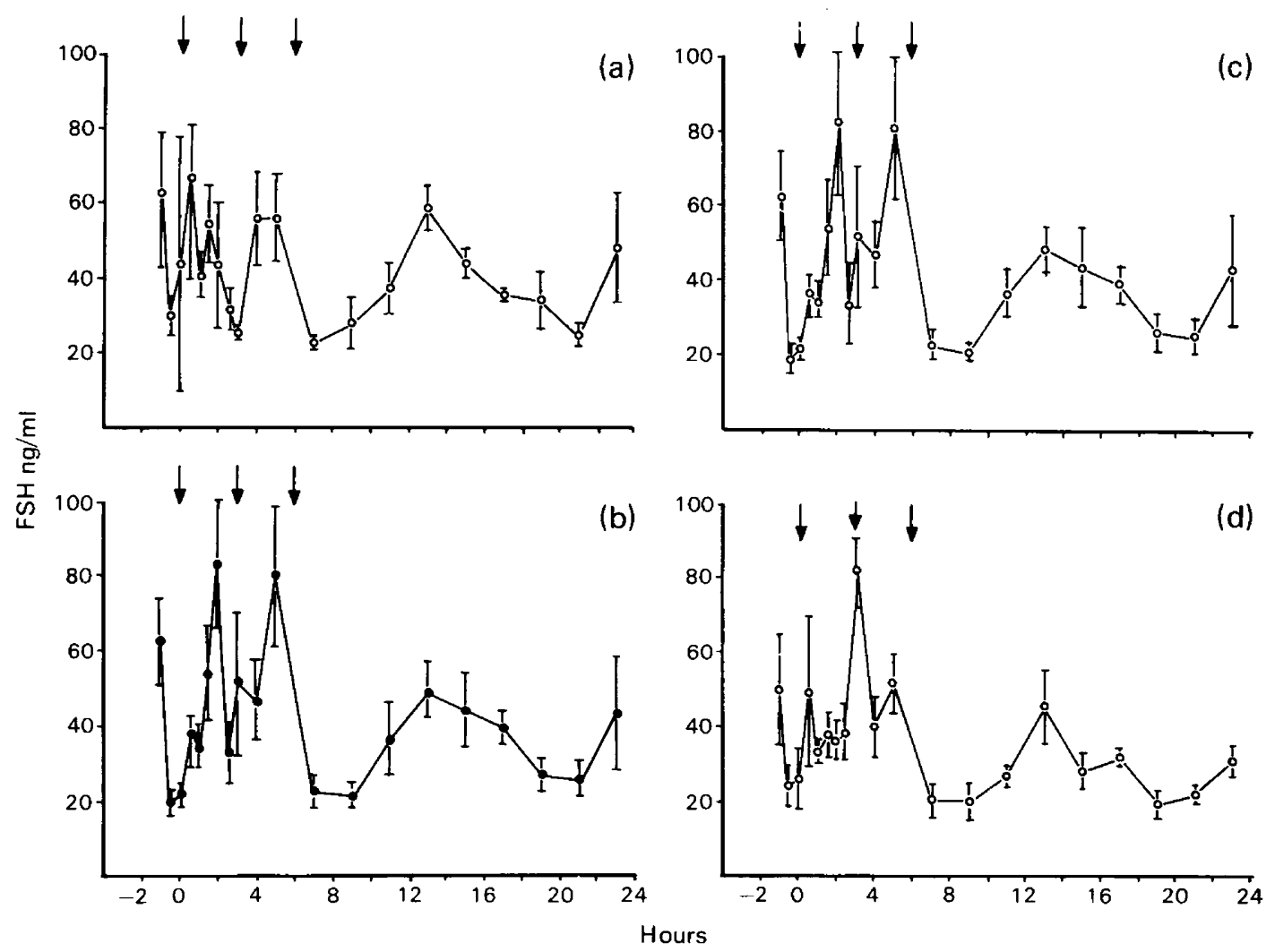

Text-fig. 4. Changes in mean \pm s.e.m. plasma concentration of FSH after 3 i.v. injections of 30 $\mu \mathrm{g} \mathrm{LH}-\mathrm{RH}$ at 90-min intervals (arrows). (a) Saline-treated controls, $\mathrm{N}=4$; (b) CB 154 injected from -5 to 0 days, $\mathrm{N}=5$; (c) $\mathrm{CB} 154$ injected from 0 to +5 days, $\mathrm{N}=5$; (d) $\mathrm{CB} 154$ injected from -5 to +5 days, $\mathrm{N}=5$, relative to day of $\mathrm{LH}-\mathrm{RH}$ treatment (Day 0 ).

\section{Ovulation and corpus luteum activity}

Treatment with LH-RH induced ovulation in 9 out of 19 ewes as judged at laparoscopy on Day 7 after LH-RH treatment. The number of animals ovulating in each group were as follows: control, 2/4; CB 154 Days -5 to $0,3 / 5$; CB 154 Days 0 to $+5,2 / 5$; CB 154 Days -5 to +5 , $2 / 5$. No changes in plasma levels of progesterone were seen in animals which did not ovulate (progesterone levels all $<0.2 \mathrm{ng} / \mathrm{ml}$ ). While plasma levels of progesterone increased within the normal range from 0 to 3 days after treatment in animals which ovulated, this increase was not sustained and in 8 out of 9 animals progesterone levels declined to basal values $(<0 \cdot 1 \mathrm{ng} / \mathrm{ml})$ by Day 9. In the 9th ewe which had been treated with CB 154 for 10 days $(-5$ to +5 days) progesterone levels showed a small increase up to Day 4 , became undetectable $(<0 \cdot 1 \mathrm{ng} / \mathrm{ml})$ on Day 6 and then increased progressively from Day 8 to values equivalent to those in the normal early luteal phase of the cycle $(1.5 \mathrm{ng} / \mathrm{ml})$.

\section{Discussion}

The results of the present study confirm previous reports that LH-RH can be used to induce ovulation as judged by the presence of a $\mathrm{CL}$ in anoestrous ewes (by injection: Foster \& Crighton, 1973; Crighton et al., 1975; by infusion: Shareha et al., 1976). 
The results also confirm that the $\mathrm{CL}$ formed fails to secrete progesterone in amounts equivalent to those seen during the luteal phase of the normal oestrous cycle (Crighton et al., 1973, 1975; Haresign et al., 1975; Shareha et al., 1976). Treatment with CB 154 with concomitant reduction in plasma levels of prolactin did not affect the basal plasma levels of $\mathrm{LH}$ or $\mathrm{FSH}$, or the occurrence of ovulation, confirming previous observations when CB 154 was given to ewes during the oestrous cycle (Niswender, 1974) or during anoestrus when ovulation was induced by treatment with oestradiol benzoate (R. B. Land, W. R. Carr \& A. S. McNeilly, unpublished observations). The failure of progesterone secretion from all $C L$ regardless of the prolactin status does not support the hypothesis that high levels of prolactin directly inhibit progesterone secretion by the CL (Rhind et al., 1978). It is possible that prolactin may directly suppress progesterone secretion from a CL formed after the follicles have been primed with gonadotrophin before ovulation. In the study by Rhind $e t$ al. (1978) ewes were pretreated with PMSG.

Nevertheless, in the present study in the absence of exogenous gonadotrophin priming, even when prolactin levels were suppressed in two of the groups for 5 days before ovulation was induced, luteal function was still inadequate. This suggests that if high levels of prolactin are implicated in the failure of progesterone secretion, then the effect must be directed at the early stages of follicular development. This conclusion has been suggested by studies with CB 154 and sulpiride in women (Robyn et al., 1977).

It has been suggested that this failure of normal luteal function was due to an inadequate release of LH after LH-RH stimulation (Crighton et al., 1973) but this does not appear to be the case. Multiple injections of LH-RH (Crighton et al., 1975) and infusion of LH-RH (Shareha et al., 1976) appear to release amounts of LH similar to those found during the normal LH discharge in the oestrous cycle. Further, in the present study it is apparent that the occurrence of ovulation is not dependent on the amount of $\mathrm{LH}$ released in response to LH-RH treatment. Ovulation occurred in one ewe releasing a cumulative total of only $78 \mathrm{ng} \mathrm{LH} / \mathrm{ml}$ whereas no ovulation occurred in another ewe in which the cumulative total was $252 \mathrm{ng} \mathrm{LH} / \mathrm{ml}$. These results would support the concept that in anoestrus ovulation depends on the status of follicles within the ovary and not on the exposure of the follicle to an ovulatory surge of LH. This is supported by the observations of Hutchinson \& Robertson (1966) and Haresign (1975) that in mid-anoestrus there were no follicles of a size which would normally ovulate $(>5.5 \mathrm{~mm}$ in diameter). The present experiment was carried out in early August. Scottish Blackface ewes do not start oestrous cycles until the end of September (Wheeler \& Land, 1977). Thus these animals were probably 8 weeks from spontaneous ovulation yet 9 out of 19 had follicles which ovulated in response to an LH-RH-induced surge of $\mathrm{LH}$.

The difference in the pattern of FSH release in those animals which ovulated compared to those which did not is of considerable interest. While the total amount of FSH released over $19 \mathrm{~h}$ of observation after LH-RH injection was the same the amount of FSH released immediately after LH-RH ( 0 to $+7 \mathrm{~h})$ was significantly less in those animals which subsequently ovulated, indicating a change in the pattern of release. The FSH response in animals which ovulated was similar to the changes in FSH seen during spontaneous oestrus in the ewe when a secondary rise in FSH occurs 12-24 h after the rise in FSH which occurs at the time of the preovulatory $\mathrm{LH}$ discharge (L'Hermite, Niswender, Reichert \& Midgley, 1972; Pant, Hopkinson \& Fitzpatrick, 1977). The basal levels of FSH in the sheep appear to decrease as oestrogen secretion increases during the period of oestrus (L'Hermite et al., 1972; Pant et al., 1977) and oestradiol-17ß inhibits the basal output of FSH from sheep pituitary cells in vitro (Miller, Knight, Grimek \& Gorski, 1977). The smaller initial increment in FSH after LH-RH stimulation seen in the present study may thus represent the effects of greater oestrogen secretion from a follicle which is capable of ovulating. Ovarian secretion of oestradiol is maintained during anoestrus (Martensz et $a l ., 1976$ ) and increases in response to LH stimulation (Scaramuzzi \& Baird, 1977). In the sheep oestradiol is secreted almost exclusively from the largest non-atretic follicle (Hay \& Moor, 
1975; Baird \& Scaramuzzi, 1976) and therefore the lower initial FSH release occurring only in the animals ovulating would suggest that the difference in response pattern for FSH is mediated by ovarian steroids.

The occurrence of ovulation after $\mathrm{LH}-\mathrm{RH}$ treatment is apparently not dependent on the amount of LH or FSH released at the time of ovulation but on the status of the follicles within the ovary. This conclusion supports data obtained from pretreatment of anoestrous ewes with PMSG before induced ovulation which resulted in normal luteal function (Haresign \& Lamming, 1978). It further suggests that the failure of progesterone secretion from the CL which is formed when ovulation does occur is not related to a direct action of the high levels of prolactin associated with anoestrus. If prolactin is involved in the reduced progesterone secretion then this involvement must be related to an effect of elevated prolactin levels on the very early stages of follicular development, a situation similar to that in women (Robyn et al., 1977).

We thank Miss N. A. Anderson, Miss M. Fordyce, Mr R. Preece and the staff at ABRO Field Station for care of the animals and Miss B. Anderson and Mrs E. MacDonald for performing the radioimmunoassays. Reagents for the radioimmunoassays were kindly supplied by Dr S. S. Lynch and Dr L. E. Reichert, Jr and the NIAMDD.

\section{References}

Baird, D.T. \& Scaramuzzi, R.J. (1976) Changes in the secretion of ovarian steroids and pituitary luteinizing hormone in the periovulatory period in the ewe: the effect of progesterone. J. Endocr. 70, 237-245.

Baird, D.T., Burger, P.R., Heavon-Jones, F.D. \& Scaramuzzi, R.J. (1974) The site of secretion of androstenedione in non-pregnant women. $J$. Endocr. 63, 201-212.

Crighton, D.B., Foster, J.P., Haresign, W., Haynes, N.B. \& Lamming, G.E. (1973) The effects of a synthetic preparation of gonadotrophin releasing factor on pituitary and ovarian function in anoestrous ewes. $J$. Physiol., Lond. 231, 98P-99P.

Crighton, D.B., Foster, J.P., Haresign, W. \& Scott, S.A. (1975) Plasma LH and progesterone levels after single or multiple injections of synthetic LH-RH in anoestrous ewes and a comparison with levels during the oestrous cycle.J. Reprod. Fert. 44, 121-124.

Foster, J.P. \& Crighton, D.B. (1973) Preliminary observations on the administration of a synthetic preparation of gonadotrophin releasing factor to cyclic and anoestrous ewes. J. Endocr. 57, xxv.

Haresign, W. (1975) Ovarian response to synthetic LHRH in anoestrous ewes. J. Reprod. Fert. 44, 127 129.

Haresign, W. \& Lamming, G.E. (1978) Comparison of LH release and luteal function in cyclic and $\mathrm{LH}-\mathrm{RH}$ treated anoestrous ewes pretreated with PMSG or oestrogen. J. Reprod. Fert. 52, 349-353.

Haresign, W., Foster, J.P., Haynes, N.B., Crighton, D.B. \& Lamming, G.E. (1975) Progesterone levels following treatment of seasonally anoestrous ewes with synthetic luteinizing hormone-releasing hormone. $J$. Reprod. Fert. 43, 269-279.

Hay, M.F. \& Moor, R.M. (1975) Functional and structural relationships in the Graafian follicle population of the sheep ovary. J. Reprod. Fert. 45, 583593.
Hutchinson, J.S.M. \& Robertson, H.A. (1966) The growth of the follicle and corpus luteum in the ovary of the sheep. Res. Vet. Sci. 7, 17-24.

Land, R.B., Wheeler, A.G. \& Carr, W.R. (1976) Seasonal variation in the oestrogen induced $\mathbf{L H}$ discharge of ovariectomized Finnish Landrace and Scottish Blackface ewes. Annls Biol. anim. Biochim. Biophys. 16, 521-528.

Legan, S.J., Karsch, F.J. \& Foster, D.L. (1977) The endocrine control of seasonal reproductive function in the ewe: A marked change in the response to the negative feedback action of estradiol on luteinizing hormone secretion. Endocrinology 101, 818824.

L'Hermite, M., Niswender, G.D., Reichert, L.E., Jr \& Midgley, A.R., Jr (1972) Serum follicle-stimulating hormone in sheep as measured by radioimmunoassay. Biol. Reprod. 6, 325-332.

Martensz, N.D., Baird, D.T., Scaramuzzi, R.J. \& Van Look, P.F.A. (1976) Androstenedione and the control of luteinzing hormone in the ewe during anoestrus. J. Endocr. 69, 227-237.

McNatty, K.M., Sawers, R.S. \& MeNeilly, A.S. (1974) A possible role of prolactin in control of steroid secretion by the human Graafian follicle. Nature, Lond. 250, 653-655.

MeNeilly, A.S. (1979) Effects of lactation on fertility. Br. Med. Bull. 35 (in press).

McNeilly, A.S. \& Andrews, P. (1974) Purification and characterization of caprine prolactin. $J$. Endocr. 60, 359-367.

McNeilly, J.R., McNeilly, A.S., Walton, J.S. \& Cunningham, F.J. (1976) Development and application of a heterologous radioimmunoassay for ovine follicle-stimulating hormone. J. Endocr. 70, 69-79.

Miller, W.L., Knight, M.M., Grimek, H.J. \& Gorski, J. (1977) Estrogen regulation of follicle stimulating 
hormone in cell cultures of sheep pituitaries. Endocrinology 100, 1306-1316.

Niswender, G.D. (1974) Influence of $2 \alpha$-Br-ergocryptine on serum levels of prolactin and the oestrous cycle in sheep. Endocrinology 94, 612-615.

Pant, H.C., Hopkinson, C.R.N. \& Fitzpatrick, R.J. (1977) Concentration of oestradiol, progesterone, luteinizing hormone and follicle-stimulating hormone in the juglar venous plasma of ewes during the oestrous cycle. J. Endocr. 73, 247-255.

Rhind, S.M., Chesworth, J.M. \& Robinson, J.J. (1978) A seasonal difference in ovine peripheral plasma prolactin and progesterone concentrations in early pregnancy and in the relationship between the two hormones. J. Reprod. Fert. 52, 59-81.

Robyn, C., Delvoye, P., Van Exter, C., Vekemens, M., Caufriez, A., de Nayer, P., Delogne-Desnock, J. \& L'Hermite, M. (1977) Physiological and pharmacological factors influencing prolactin secretion and their relation to human reproduction. In Prolactin and Human Reproduction, pp. 71-96. Eds P. G. Crosignani \& C. Robyn. Academic Press, London.
Scaramuzzi, R.J. \& Baird, D.T. (1977) Pulsatile release of luteinizing hormone and the secretion of ovarian steroids in sheep during anestrus. Endocrinology 101, 1801-1806.

Shareha, A.M., Ward, W.R. \& Birchall, K. (1976) Effects of continuous infusion of gonadotrophinreleasing hormone in ewes at different times of the year. J. Reprod. Fert. 46, 331-340.

Tyndale-Biscoe, C.H. \& Hawkins, J. (1977) The corpora lutea of marsupials: aspects of function and control. In Reproduction and Evolution, pp. 245-252. Eds. J. H. Calaby and C. H. Tyndale-Biscoe. Australian Academy of Science, Canberra.

Walton, J.S., MeNeilly, J.R., MeNeilly, A.S. \& Cunningham, F.J. (1977) Changes in blood levels of prolactin, LH, FSH and progesterone during anoestrus in the ewe. $J$. Endocr. 75, 127136.

Wheeler, A.G. \& Land, R.B. (1977) Seasonal variation in oestrous and ovarian activity of Finnish Landrace, Tasmanian Merino and Scottish Blackface ewes. Anim. Prod. 24, 363-376.

Received 22 November 1978 